\title{
An assessment of the socio-economic and ecological impacts of environmental changes on rural livelihood: A study across Addado, Buhodle and Northern Galkaayo of central and northern Somalia
}

\author{
Badal Ahmed Hassan ${ }^{1}$, Edinam K. Glover ${ }^{2, ~ *, ~ O l a v i ~ L u u k k a n e n ~}{ }^{1}$, Ramni Jamnadass ${ }^{3}$, \\ Ben Chikamai $^{4}$ \\ ${ }^{1}$ Viikki Tropical Resources Institute, Department of Forest Sciences, University of Helsinki, Helsinki, Finland \\ ${ }^{2}$ Faculty of Law, University of Helsinki, Helsinki, Finland \\ ${ }^{3}$ World Agroforestry Centre (ICRAF), United Nations Avenue, Gigiri, Nairobi, Kenya \\ ${ }^{4}$ Kenya Forestry Research Institute, Nairobi, Kenya
}

\section{Email address:}

badal.hassan@helsinki.fi (B. A. Hassan), eddie.glover@helsinki.fi ( E. K. Glover), Olavi.Luukkanen@helsinki.fi (O. Luukkanen), r.jamnadass@cgiar.org (R. Jamnadass), b.chikamai@kefri.org (B. Chikamai)

\section{To cite this article:}

Badal Ahmed Hassan, Edinam K. Glover, Olavi Luukkanen, Ramni Jamnadass, Ben Chikamai. An Assessment of the Socio-Economic and Ecological Impacts of Environmental Changes on Rural Livelihood: A Study Across Addado, Buhodle and Northern Galkaayo of Central and Northern Somalia. Agriculture, Forestry and Fisheries. Vol. 3, No. 4, 2014, pp. 279-291. doi: 10.11648/j.aff.20140304.20

\begin{abstract}
The international community has long recognized desertification as a significant global social, economic and environmental problem of concern with detrimental effects on the livelihoods of people in many countries world-wide. To explore this critique, this study examined local people's views on the causes, effect and socio-economic impact of desertification and degradation to the community. The study involved a cross-sectional survey conducted with four community categories, namely nomadic pastoralist, agro-pastoralists, villagers and Internally Displaced Persons (IDPs), from Addado, Buhodle and northern Galkaayo of central and northern part of Somalia; through questionnaire-based interviews. Descriptive statistics attribute environmental changes to negative implications of human activities on the environment: the menace of which led to a decline in forage, current loss of biodiversity and the related changes in the environment, permanent migration, increased poverty and health problems. The startling results of this study conclusively demonstrate that the challenges involve proper interventions for tree planting against desertification as well as for community empowerment through public education and formation of community based environmental associations to coordinate the overall environmental management activities and to raise public awareness.
\end{abstract}

Keywords: Addado, Buhodle, Central Somalia, Desertification, Northern Galkaayo, Nordern Somalia, Rural Livelihoods, Socio-Economic Impacts

\section{Introduction}

\subsection{Drylands}

As defined by United Nations Convention to Combat Desertification (UNCCD) drylands comprise land within the arid, semi-arid and dry sub-humid areas. Aridity is defined based on an Aridy Index, which is determined by the ratio of the precipitation $(\mathrm{P})$ to the potential evapo-transpiration (PE).

Most arid, semi-arid and dry sub-humid zones simultaneously experience rises in temperature and declines in rainfall pattern. Drylands may be defined in several ways but the simplest way, according to [28], is to use a measure of aridity which represents a lack of moisture in the average climatic conditions. Dryness can be classified using the "Aridity Index (AI)", or "dryness ratio (P/PET)", which is the ratio of the mean annual precipitation $(\mathrm{P})$ and the mean annual potential evapotranspiration (PET). PET is the maximum amount of moisture which can evaporate from a surface and transpire through vegetation under given atmospheric conditions, assuming there is no limit to the 
amount of moisture available. According to [8], the arid, semi-arid and dry sub-humid climatic zones, which fall within UNCCD focus, are areas, other than polar and sub-polar regions, in which the ratio of annual precipitation to potential evapotranspiration falls within the range from 0.05 to 0.65 [13]. Aridity zones are classified according to aridity index: $<0.05$ hyper-arid $(7.5 \%$ of the world covered); $0.05-0.20$ arid (12.1\% of the world covered); $0.2-0.50$ semi-arid (17.7\% of the world covered); 0.50-0.65 dry sub-humid (9.9\% of the world covered) [8].

Drylands cover 40 percent of the world's land area and host one third of world's population [24]. Two-thirds of rural population in sub-Saharan Africa (SSA) live in arid and semi-arid areas or area with poor infrastructure $[15 ; 40]$.

\subsection{Sahel, Drought and Desertification}

Climatologically, the Sahel describes a period of abnormally dry weather sufficiently prolonged for the lack of water to cause serious hydrologic imbalance in the affected area [14]. It is characterized by frequent droughts, low precipitation, poorly distributed and highly variable monthly and seasonal unpredictable rainfall. During drought periods where there is such long spell of dry weather, desertification $^{1}$ becomes harsher, as well as more noticeable, and its rate of incidence increases abruptly. As the likelihood of droughts rises as one moves from the humid to the more arid regions, so too, does the susceptibility to desertification. It is known that natural resources such as land forms, soils and vegetation are often transformed during such long spell of dry weather. In this way drought epitomizes an "indirect" cause of desertification owing to its possible exacerbation of poor land use, a direct cause of desertification as it induces degradation $^{2}$ of soil and vegetation $[26 ; 8]$

Dryland ecosystems tend to be naturally dynamic instability systems. According to [36], several dryland communities experience a high level of responsiveness to precipitation when it falls but in turn exhibit very insignificant productivity. It is sometimes difficult to determine if a particular vegetation condition is a direct reaction to unfavorable short-term environmental conditions (mostly drought) or is actually a reflection of long duration or irreversible degradation. According to [10] and [26], desertification is influenced by factors such as prevalent climate of rural poverty, ignorance, greed, social and economic changes or misguided government policies while [32] added that protracted drought may spur the rate of desertification.

According to [16] the United Nations Environment Programme (UNEP) has estimated that a total of 35 million

\footnotetext{
1 "Desertification is land degradation in the arid, semi-arid and dry sub-humid regions resulting from various factors, including climatic variations and human activities" (UNEP 1994).

2 "Degradation implies reduction of resource potential by one or combination of processes acting on land. These processes include water erosion, wind erosion and sedimentation by those agents, long-term reduction in the amount of diversity of natural vegetation, where relevant, and salinization and sodication" [17].
}

$\mathrm{km}^{2}$ of the world's range, rainfed crop land and irrigated land - an area about the land area of North and South America combined - undergoes the desertification and degradation processes. According to a 1991 UNEP assessment, about 850 million people (one-sixth of the world's population) suffer from desertification and land degradation processes [17]. [10] reported that desertification and land degradation affect drylands worldwide but tends to be more pronounced in Asia and Africa, each of which accounts for $37 \%$ of all desertified land [8].

\subsection{Somalia's Environmental Challenges}

Agro-ecologically, Somalia is arid and semi-arid land with the rainfall ranging from less than $50 \mathrm{~mm} /$ year along the northern coast to about $600 \mathrm{~mm} /$ year in the southernmost regions of the country and the potential evapo-transpiration between 1900 and $2500 \mathrm{~mm}$ [5].

With abundant grazing land, over $70 \%$ of the Somali population are nomadic pastoralists; thereby pastoralism ${ }^{3}$ and agro-pastoralism ${ }^{4}$ are common systems of land production and the primary source of livelihoods; therefore, these natural resources form the basis of rural livelihoods in Somalia.

The terrestrial ecosystems of the country are threatened by continuous deforestation, degradation and diminution, with far-reaching ecological, economic and social consequences. The most common vegetation types in Somalia are Acacia-commiphora woodland which is defined as open stands of trees of at least $8 \mathrm{~m}$ tall with a canopy cover of 40 percent or more dominated by Acacia and Commiphora genus, bush-land ${ }^{5}$ and shrub-land ${ }^{6}$ [21].

Somalia has witnessed the great damage caused by the long civil war, especially in the fields of agriculture, forestry and education. There is a great deal of challenges of environmental concerns facing Somalia, which is far less studied. The country suffers from almost all types of environmental issues such as famine; use of contaminated water contributes to human health problems; deforestation; overgrazing; soil erosion; and, desertification. The country is prone to recurring droughts; frequent dust storms over eastern plains in summer; and floods during rainy season. In most areas of the country particularly Addado and Galkaayo, woodlands have turned into scrub and the ground vegetation has disappeared from extensive areas. The strong indicators emphasizing the seriousness of the problems are: reduced agricultural productivity and food insecurity, combined with dominance of less vegetative cover, as well

\footnotetext{
${ }^{3}$ Pastoral production systems are those in which $50 \%$ of gross household revenue (i.e. the total value of marketed production plus the estimated value of subsistence production consumed within the household) comes from livestock-related activities (Marton and Meadows 2000).

${ }^{4}$ Agro-pastoralists are those in which more than $50 \%$ of household gross revenue comes from farming, and 10-50\% from livestock (Morton and Meadows 2000).

${ }^{5}$ Bushlands are open stands of bushes (usually between 3 and $7 \mathrm{~m}$ tall) with a canopy cover of 40 percent or more

${ }^{6}$ Shrublands are open or closed stands of shrubs up to $2 \mathrm{~m}$ tall
} 
as extinction of wildlife species. In short, the area could best be described as "an overgrazing endpoint where most of the grass and topsoil has already gone" [9].

There are hardly any studies that seek to understand the implications of such causes and impacts of desertification on the environment, and on socio-economic conditions of local people and how to tackle the major environmental problems faced in Somalia. The purpose of this study therefore is to fill in this gap in our knowledge and to draw out recommendations for social development. In view of these developments, this study focuses on describing and analyzing the subject in relation to Addado, Buhodle and Galkaayo in Somalia. The study adds one small case study to our understanding of environmental change, in this case, Somalia. In an attempt to continue the transformation toward stability and sustainability in Somalia, it is important that the connection between social and environmental issues relating to resource extraction practices are more clearly understood.

\section{Material and Methods}

\subsection{Bio-Physical and Socio-Economic Conditions}

\subsubsection{Study Area}

This research was conducted in three SAHANSAHO project $^{7}$ areas, namely, Addado, Buhodle and Galka,ayo of central and northern Somalia (Fig. 5) between April and May 2012.

Addado lies between latitude $05^{\circ} 53^{\prime} 64^{\prime \prime} \mathrm{N}$ and longitude $46^{\circ} 37^{\prime} 65^{\prime \prime} \mathrm{E}$; Buhodle lies between latitude $08^{\circ} 13^{\prime} 59^{\prime \prime} \mathrm{N}$ and longitude $46^{\circ} 21^{\prime} 80^{\prime \prime} \mathrm{E}$ and Galkaayo lies between latitude $06^{\circ} 50^{\prime} 91^{\prime \prime} \mathrm{N}$ and longitude $47^{\circ} 26^{\prime} 49^{\prime \prime} \mathrm{E}$. The three study locations have in general similarities in terms of climate, topography and socio-economic conditions.

\subsubsection{Bio-Physical Conditions}

\subsubsection{Climate}

Climatologically the project areas lie in the arid zones prone to drought. The rainfall is scarce and erratic in the region with two rainy seasons, the spring season locally known as " $g u$ " from March to May and the autumn season locally known as "dayr" lasting from October to December.

The annual average rainfall lies between $150 \mathrm{~mm}$ to 300 mm [23], (Fig. 4). Due to relatively high altitude, Buhodle receives a higher rainfall ranging between 250 and $400 \mathrm{~mm}$ per annum. The higher precipitation in these areas enables more vegetation cover compared to the other two areas. The major rainfall season lasts from April-May and minor rainfall season lasts from October-November. There are no perennial rivers, and there is heavy reliance on boreholes and rainwater harvesting as permanent sources of water for human beings and livestock. The area has a mean annual temperature of $28{ }^{\circ} \mathrm{C}$. The hottest months are January to

\footnotetext{
${ }^{7}$ SAHANSAHO project is a Finnish Somalia Network initiative in response to the environmental changes in Somalia; financed by the Ministry for Foreign Affairs of Finland.
}

March, during these months temperatures exceed $30{ }^{\circ} \mathrm{C}$. June to September is the coolest time of the year.

\subsubsection{Vegetation}

Generally, the vegetation of the zone is bushland and shrubland (see Fig.1, Fig.2 and Fig. 3). To some extent, Acacia-Commiphora woodland can be found in Buhodle (Fig. 3). The three most common tree genera are Acacia, Boswellia and Commiphora.

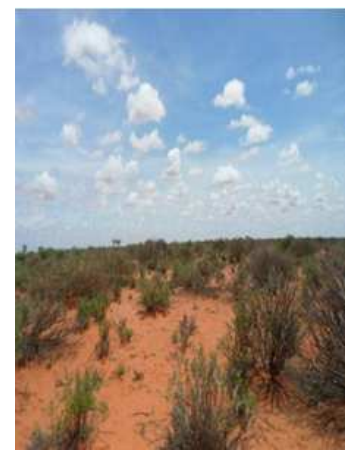

Figure 1. Addado (Photo: Abdikadir M. Abdi)

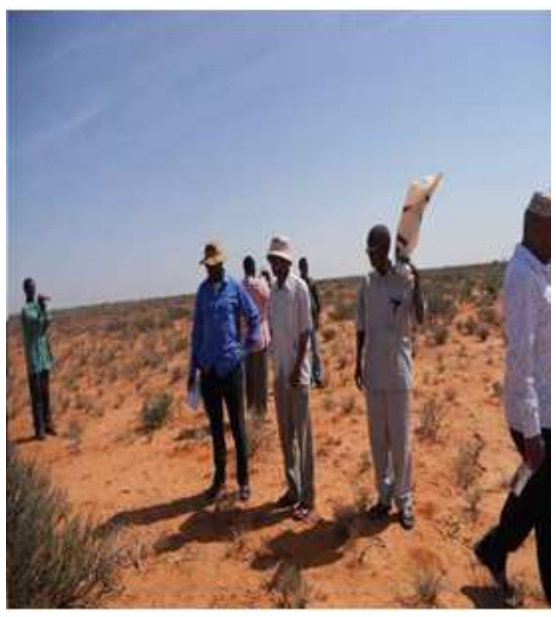

Figure 2. Galkaayo (Photo:Mustafa A/asis)

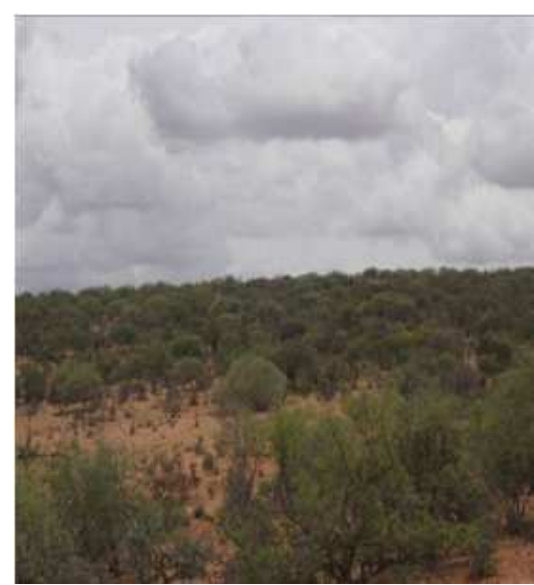

Figure 3. Buhodle (Photo: Badal A. Hassan). 


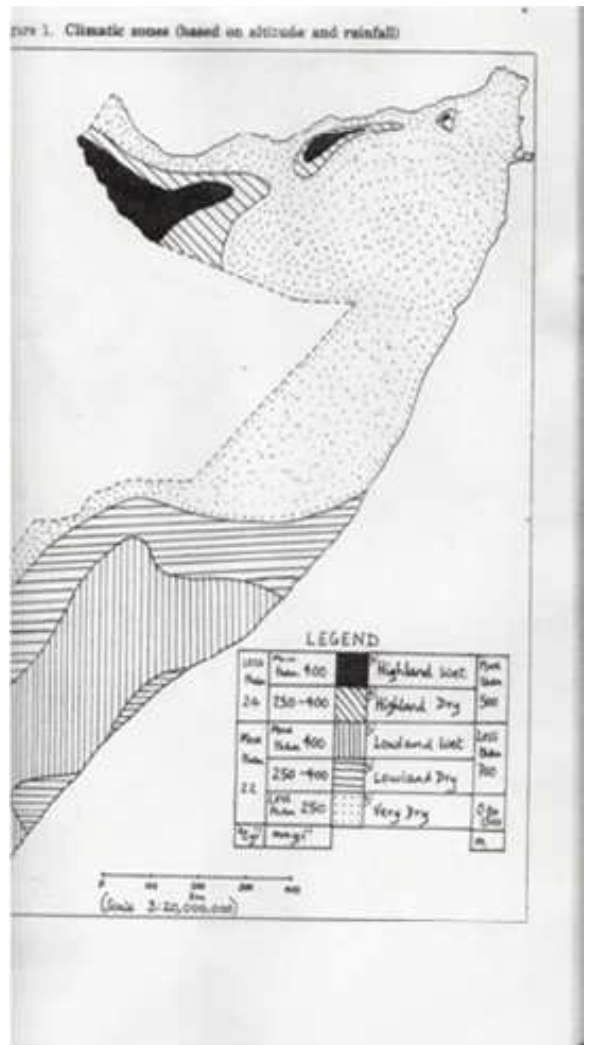

Figure 4. Climate characterization map of Somalia

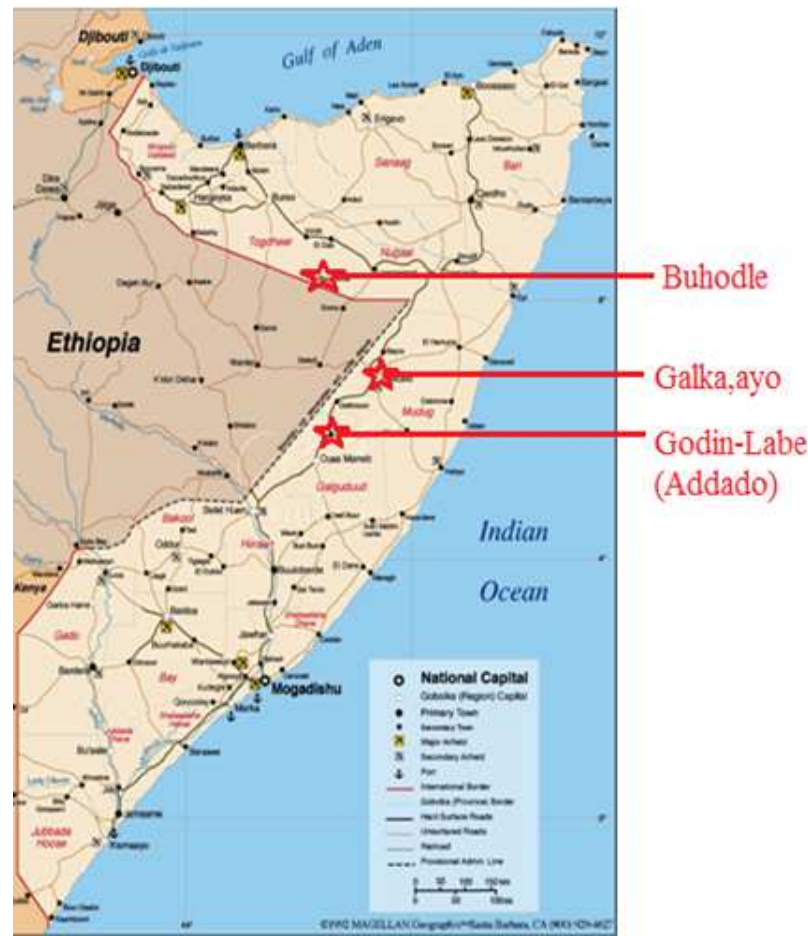

Figure 5. Map of Somalia showing the study area (modified from [23].

\subsubsection{Topography and Soils}

The area consists largely of featureless plain, prone to flooding during rainy season often making roads impassable. However, there are some scattered hills in Buhodle and Galkaayo.
The plain rises from an altitude of $309 \mathrm{~m}$ above sea level in Addado and Galkaayo and $366 \mathrm{~m}$ above sea level in Buhodle. The area is flat with three different types of soils: sandy soil, clay soil and lime soil.

\subsubsection{Social and Land-Use Characteristics}

Population and Main economic activity

The estimated population of the three study areas is 315,000 , with annual population growth rate of $3.7 \%$; with more than $50 \%$ of the population is younger than 26 years old. The population has an average family size of six members. Over $70 \%$ of the population of the area are nomadic pastoralists of the Somali ethnic group. They rear camels, cattle, sheep and goats and their livelihood activities revolve around sale of livestock and livestock products. Other sources of income are purchase of grain and other commodities, formal employment, and non-timber forest products (NTFPs) collection. Their diet consists mainly of meat, milk and grain.

The pastoral people in the area practice seasonal migration to access pasture, settling near to water sources and good pasture for a few weeks before moving on. Those who cannot travel long distances, mostly women, children and the elderly are left behind and are settled around boreholes/reservoirs or settlements. Due to prolonged civil war and frequent droughts, large number of nomadic pastoral communities lost their livestock, thereby falling back to sedentary life and settling in the outskirts of the major towns as Internally Displaced Persons (IDPs) and depending on food aid.

\subsection{Methodology}

\subsubsection{Sampling and Data Collection}

Data were collected based on a questionnaire as well as group discussions to gather information from the households and from village leaders, special groups and key informants. Data collection involved standardised as well as open-ended questions. The informants were asked to list the declining tree species in their own language. The information given by the respondents was clarified and completed by observation in and near the project site.

Data were gathered from both primary and secondary sources. Primary data were obtained by using a pre-tested semi-structured questionnaire. Interviews were conducted with key informants, ${ }^{8}$ village leaders and special groups among study village residents in Addado, Buhodle and northern Galkaayo. Data was collected on household and land-use characteristics: Main source of household income, sources of water, sources of energy, land tenure security, environmental degradation and the causes of the degradation in the project area, socio-economic impacts of degradation, management of forest resources and participation of farmers in tree planting activities.

\footnotetext{
${ }^{8}$ Key informants are experts, elderly people and most knowledgeable people on particular topics. Key informants' impressions were used to cross-reference the validity of the different variables employed in the questionnaire [8].
} 
To every interviewee, the purpose of the research and its importance was explained by the interviewer in order to build confidence in the participants to respond to all questions. The importance of the key informants' interview lay in obtaining reliable, thorough and in-depth results on aggregate data at the community level for the study area. Key informants' impressions were used to cross-reference the validity of the different variables employed in the questionnaire in the study area [8].

The household questionnaire was collected from the households dependent or not dependent on plant resources. During the field survey, four distinctive groups were selected to carry out the socio-economic questionnaire survey using structured questionnaire: A survey of 90 households consisting of 30 households in each study area was carried out at Buhodle, Galkaayo and Addado between 20 April and 14 May, 2012. A representative sample of 33 nomadic pastoralists, 9 agro-pastoralists, 19 Villagers and 29 Internally Displaced Persons (IDPs) were randomly selected for the study. Respondents were selected by a simple random sampling procedure, which was representative of the farming system categories in the three project areas.

Brief description is given of the categories in the following paragraphs.

\subsubsection{Pastoralists}

According to [1], nomadic pastoralists; depend on domesticated livestock and migrate in an established territory to find pasture for their livestock. Most groups have focal sites that they occupy for considerable periods of the year. Pastoralists may depend entirely on their herds or may also hunt or gather, practice some agriculture or trade with agricultural peoples for grain crops between seasonal migrations. The patterns of pastoral migration are many, often depending on the type of livestock, the topography, and the climate. The pastoral communities in the Sahelian zone (from Niger to Somalia) are the best example of this type of nomadism.

In this study, nomadic pastoralists were defined as those who get more than $50 \%$ of their livelihood from livestock and livestock-related products. Pastoralism has long been an integral part of dryland inhabitants' history, land use and economy.

\subsubsection{Agro-Pastoralists}

As mentioned earlier, the three project areas are arid and semi-arid lands, which give little opportunity for crop farming, however, there are some few places where some locals practice agriculture. Agro-pastoralists are farmers who practice mixed farming with livestock and rainfed agriculture. They are also considered in this study as those who earn more than $50 \%$ of their livelihood from crop production and the rest from livestock products. They represent the second most important category and encompass both the original inhabitants and immigrants from high- potential areas. Rainfed agriculture refers to the type of agriculture practiced during the rainy season, using early maturing crops and/or along riverine flood plains and adjoined interfluves.

\subsubsection{Villagers}

Apart from pastoralism and agro-pastoralism, most of the urban dwellers, in either bigger towns like Galkaayo or other towns like Addado and Buhodle, earn their livelihood from other sources, other than livestock or crop production. They are either formal employees earning salary or informal employees e.g. shop owners, firewood collectors, charcoal burners, resin collectors etc. On the basis of foregoing, villagers are classified as those who derive more than $50 \%$ of their daily livelihood from either formal or informal employment, other than livestock rearing or crop production.

\subsubsection{Internally Displaced Persons (IDPs)}

Internally Displaced persons (IDPs), are persons or group of persons who have being forced or obliged to flee or to leave their homes or places of habitual residence in particular, as result of or in order to avoid the effects of armed conflicts, situation of generalised violence, violation of human rights, or natural or human made disasters, and who have no crossed an internationally recognised state border. Due to prolonged droughts and recent conflicts between Khatumo State and Somaliland near Buhodle many nomadic pastoralists lost their livestock or were displaced from their customary habitation area, and migrated to larger towns like Addado, Galkayo and Buhodle. The IDPs depend mainly on food aid or NTFPs. Therefore, this investigator considered them as a separate livelihood group.

\subsubsection{Group Discussions}

Group discussion was applied in order to give interviewees the chance to express themselves freely on issues under investigation and to discuss amongst themselves the problems or opportunities they might have. The group discussion served to elucidate important points and helped to verify and check the accuracy and validity of information gathered from the household questionnaire, key informants interview, and the literature review.

Sources of secondary data used in the study included grey literature and peer-reviewed documents as well as institutions involved in natural resource management in the Horn of Africa. Some of these institutions included the Viikki Tropical Resources Institute (VITRI), the Kenya Forestry Research Institute (KEFRI) and the World Agroforestry Centre (ICRAF); literature was also retrieved from libraries in Finland and Sweden and from internet sources, and the universities in Kenya. Information was also obtained from reports and files maintained by the Addado, Buhodle and northern Galkaayo.Local Councils.

\subsubsection{Data Analysis}

Data gathered from questionnaire were coded, computerized and analyzed using the Statistical Package for Social Sciences (SPSS) software. Statistical procedures allow the researcher to "reduce, summarize, organize, evaluate, interpret, and communicate numeric information". In this study, descriptive statistics were used to describe the 
demographic characteristics of the respondents and to find out the distribution of respondents over the different categories. Percentages were used as a tool of analysis for interpreting the qualitative information collected from the respondents. Descriptive statistics is a useful analytical tool that allows the researcher to examine the characteristics, behaviours, and experiences of study participants [8].

\section{Results}

\subsection{Socio-Economic Household Characteristics}

\subsubsection{Livelihood Characterization of the Respondents}

A survey of 90 households was carried out at Buhodle, Galkaayo and Addado between April and May 2012. From the target population, a representation sample of $36.3 \%$ pastoralists, $31.9 \%$ IDPs, $20.9 \%$ Villagers and $9.9 \%$ agro-pastoralist, were randomly selected for the study (Table 1).

Table 1. Characterization of the livelihood sources of the respondents.

\begin{tabular}{|c|c|c|c|c|c|}
\hline & & Frequency & Percent & Valid Percent & Cumulative Percent \\
\hline \multirow{5}{*}{ Valid } & Pastoralist & 33 & 36.7 & 36.7 & 36.7 \\
\hline & Agro-pastoralist & 10 & 11.1 & 11.1 & 47.8 \\
\hline & Villager & 19 & 21.1 & 21.1 & 68.9 \\
\hline & Internally Displaced Persons (IDPs) & 28 & 31.1 & 31.1 & 100.0 \\
\hline & Total & 90 & 100.0 & 100.0 & \\
\hline
\end{tabular}

\subsubsection{Level of Education}

The result shows that, $75.5 \%$ of the women who were interviewed were illiterate; $10.8 \%$ attained primary school level education, $5.4 \%$ had attended secondary school and $2.7 \%$ attained diploma level education. None of the women respondents were semi-literate or had attained university level education. The study also shows that $54.7 \%$ of the men respondents were illiterate, $17 \%$ attained primary school level education, $13.2 \%$ were semi-literate, $11.3 \%$ had attended secondary school and $1.9 \%$ had diploma level education; while $1.9 \%$ attended university level (Table 2).

Table 2. Level of Education in Relation to Gender.

\begin{tabular}{|c|c|c|c|c|c|c|c|c|c|}
\hline & & & \multicolumn{6}{|c|}{ Level of Education } & \multirow{2}{*}{ Tota } \\
\hline & & & Illiterate & Semi-literate & Primary school & Secondary school & Diploma & University degree & \\
\hline \multirow{8}{*}{ Gender } & \multirow{4}{*}{ Male } & Count & 29 & 7 & 9 & 6 & 1 & 1 & 53 \\
\hline & & $\%$ within Gender & 54.7 & 13.2 & 17.0 & 11.3 & 1.9 & 1.9 & 100.0 \\
\hline & & $\begin{array}{l}\% \text { within Level of } \\
\text { Education }\end{array}$ & 50.0 & 100.0 & 64.3 & 75.0 & 50.0 & 100.0 & 58.9 \\
\hline & & $\%$ of Total & 32.2 & 7.8 & 10.0 & 6.7 & 1.1 & 1.1 & 58.9 \\
\hline & \multirow{4}{*}{ Female } & Count & 29 & 0 & 5 & 2 & 1 & 0 & 37 \\
\hline & & $\%$ within Gender & 78.4 & 0.0 & 13.5 & 5.4 & 2.7 & 0.0 & 100.0 \\
\hline & & $\begin{array}{l}\% \text { within Level of } \\
\text { Education }\end{array}$ & 50.0 & 0.0 & 35.7 & 25.0 & 50.0 & 0.0 & 41.1 \\
\hline & & $\%$ of Total & 32.2 & 0.0 & 5.6 & 2.2 & 1.1 & 0.0 & 41.1 \\
\hline \multirow{4}{*}{ Total } & & Count & 58 & 7 & 14 & 8 & 2 & 1 & 90 \\
\hline & & $\%$ within Gender & 64.4 & 7.8 & 15.6 & 8.9 & 2.2 & 1.1 & 100.0 \\
\hline & & $\begin{array}{l}\% \text { within Level of } \\
\text { Education }\end{array}$ & 100.0 & 100.0 & 100.0 & 100.0 & 100.0 & 100.0 & 100.0 \\
\hline & & $\%$ of Total & 64.4 & 7.8 & 15.6 & 8.9 & 2.2 & 1.1 & 100.0 \\
\hline
\end{tabular}

\subsubsection{Main Source of Household Income}

From the economic related information of the respondents, there were various categories of alternative income sources. The result shows that $38.9 \%$ of the respondents got their livelihood support from pastoralism, $24 \%$ from informal employment, and $15.6 \%$ from formal employment, $13.3 \%$ depended on food aid and $7.8 \%$ on agro-pastoralism (Fig. 6). 


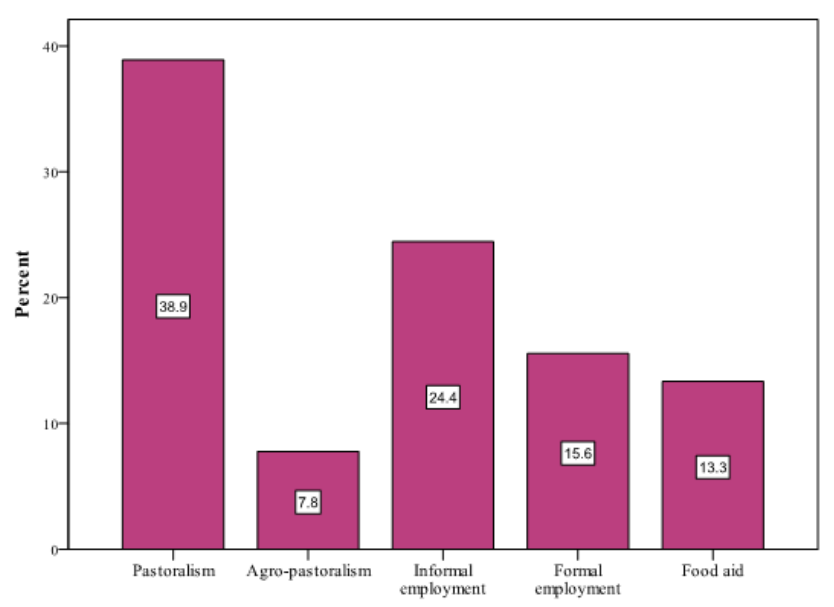

Figure 6. The Sources of Subsistence of the Respondents in the Study Area

\subsubsection{Other Sources of Household Income}

When the interviewees were asked to indicate other sources of household incomes, $38.9 \%$ mentioned remittances, $44.4 \%$ Non-Timber Forest Products (NTFPs) and 13.3 casual work(Fig.7).

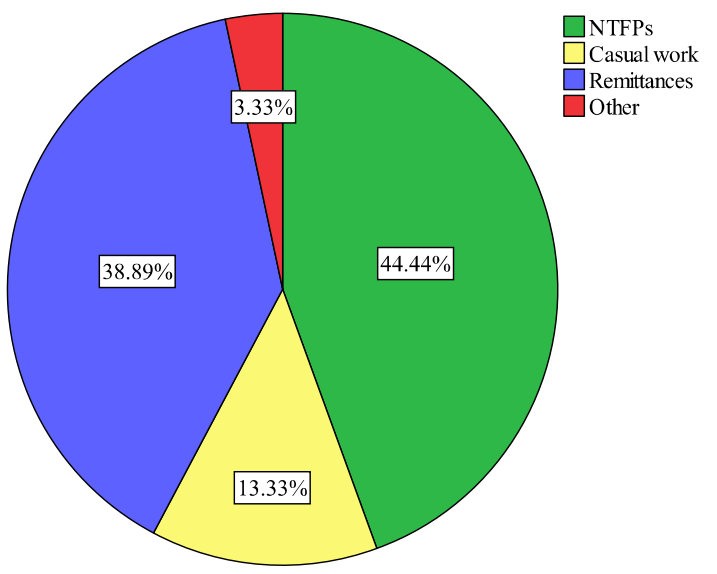

Figure 7. Other Sources of Household Income as indicated by the Respondents.

\subsubsection{Sources of Water}

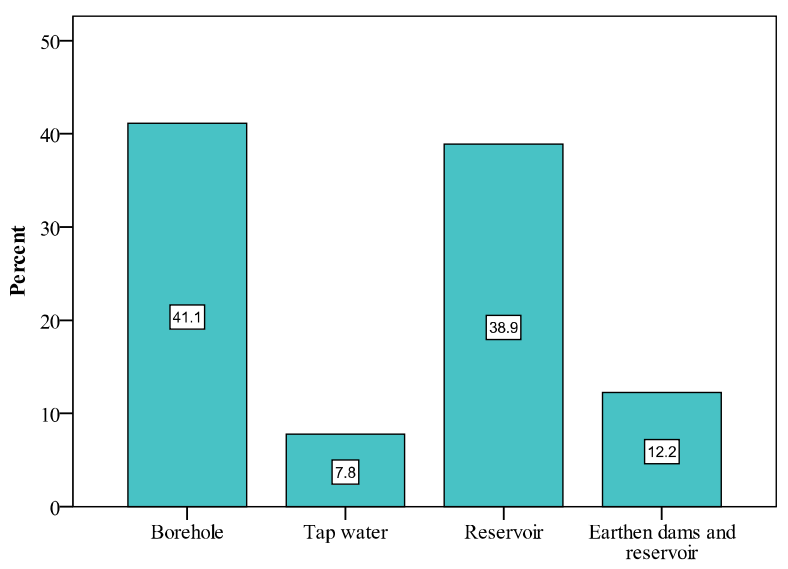

Figure 8. Respondent's Main Sources of Water.

The results reveal that $41.1 \%$ of households interviewed use borehole as main sources of water, $38.9 \%$ rely on reservoir as primary sources of water, $12.2 \%$ use earthen dams and reservoirs and only $7.8 \%$ receive water from tap (Fig. 8).

\subsubsection{Sources of Energy}

The results in Figure (9) show that, $77.8 \%$ of the respondents use firewood as source of cooking energy, $18.9 \%$ use charcoal, $2.2 \%$ kerosene and only $1.1 \%$ use electricity for cooking purpose.

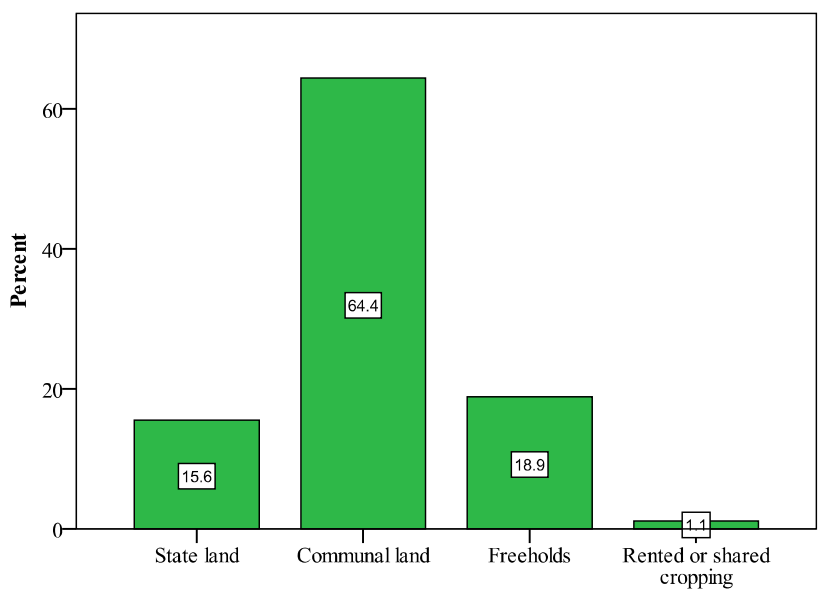

Figure 9. Sources of Energy as indicated by the Respondents.

\subsubsection{Land Tenure}

The study result shows that, four major land tenureships exist in the study areas, namely, communal land ${ }^{9}(64.4 \%)$, freehold $^{10}(18.9 \%)$, state land $(15.6 \%)$ and rented land (1.1\%) (Fig.10)

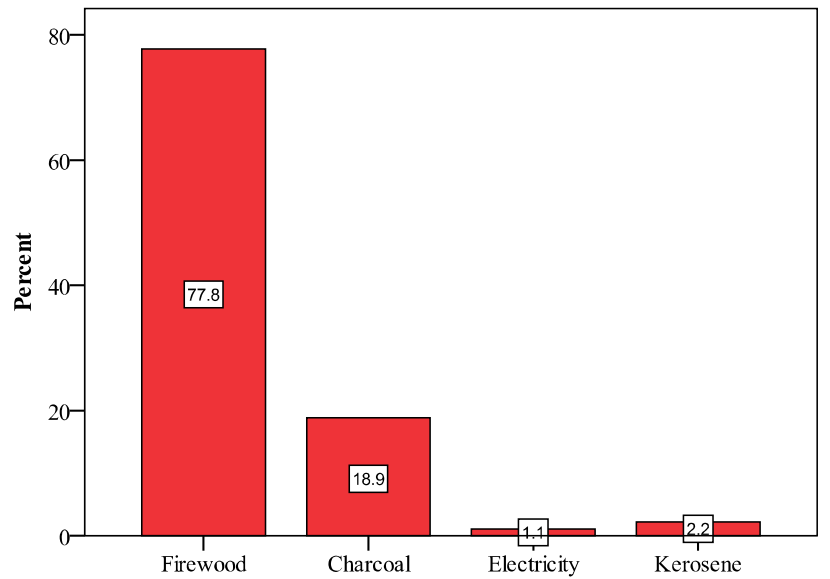

Fig 10. Land tenure-ship in the study area

\subsubsection{Causes of Environmental Degradation in the Project Area}

Ninety percent $(99 \%)$ of the respondents agreed that there is high resources and environmental degradation in each project area. There were also various causes of the resources

\footnotetext{
${ }^{9}$ Communal land: land collectively owned by particular tribes or clans.

${ }^{10}$ Freehold: Land held freely. Simply, it represents absolute ownership of real estate.
} 
reduction and the environmental changes as perceived by local people in the study areas. The number of people who referred to certain cause was interpreted as indicating the strength of that particular factor as shown in (Fig.11). The results indicate that respondents ranked the causes of resources degradation in the following order: Drought $(31.11 \%)$, charcoal burning $(28.89 \%)$, reservoir expansion $(21.11 \%)$ and Overgrazing $(18.89 \%)$.

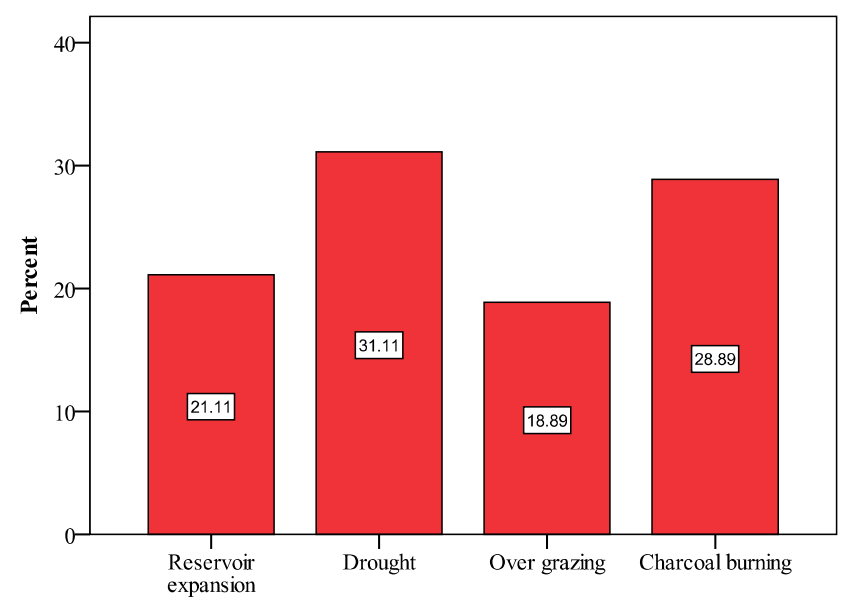

Figure 11. Major Causes of Resource Environmental Degradation.

\subsubsection{Existing Environmental}

\subsubsection{Management Practices}

The respondents were asked if there is any ongoing environmental management programs in response to the existing environmental changes, $71.1 \%$ said nothing is going on, $8.9 \%$ said tree planting activities is going one, $8.9 \%$ said community mobilization, $6.7 \%$ mentioned new environmental legislation and $4.4 \%$ said waste management (Fig. 12).

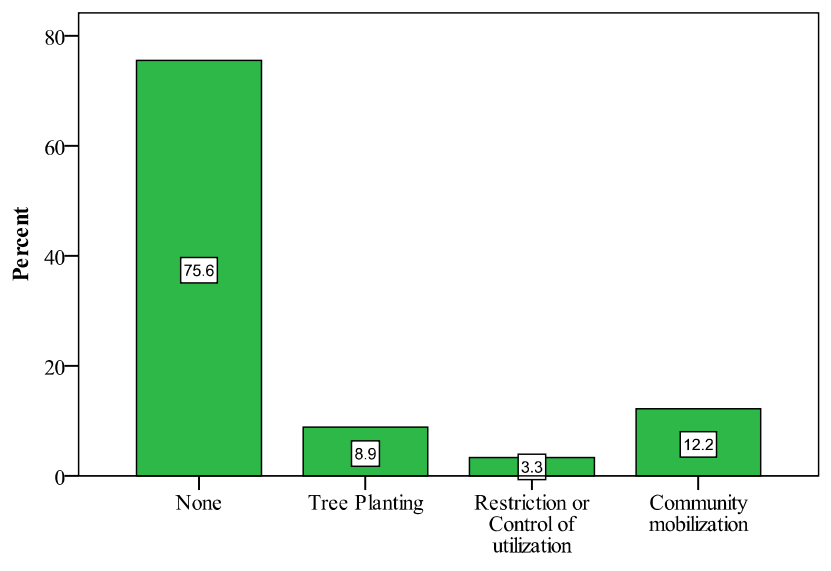

Figure 12. Natural Resources Management Practices in the Study Areas

\subsubsection{Willingness to Participate in NTR and Tree Planting for Agroforestry Purpose}

When the interviewees were asked about their willingness to participate in natural regeneration and tree planting activities for environmental rehabilitation and for agroforestry purposes $80 \%$ of men respondents and $90 \%$ of women respondents answered in affirmative that they were willing to participate. When asked which land-use zone (s) they would like to plant, however, they gave different views, $56.7 \%$ said in communal land, $26.7 \%$ said in homestead and $16.7 \%$ said in farm (Table 3 ).

Table 3. Desired Land-use Zones to Plant Trees

\begin{tabular}{|c|c|c|c|c|c|}
\hline & & Frequency & Percent & $\begin{array}{l}\text { Valid } \\
\text { Percent }\end{array}$ & $\begin{array}{l}\text { Cumulative } \\
\text { Percent }\end{array}$ \\
\hline \multirow{4}{*}{ Valid } & Farm & 15 & 16.7 & 16.7 & 16.7 \\
\hline & Homestead & 24 & 26.7 & 26.7 & 43.3 \\
\hline & $\begin{array}{l}\text { Communal } \\
\text { land }\end{array}$ & 51 & 56.7 & 56.7 & 100.0 \\
\hline & Total & 90 & 100.0 & 100.0 & \\
\hline
\end{tabular}

\section{Discussion}

\subsection{Socio-Economic Household Characteristics}

\subsubsection{Level of Education}

The survey found that, majority of the respondents had never attended school of any kind. A possible explanation is the fact that the three study areas are within the arid land with large nomadic pastoral community. The nomadic pastoralist, have no permanent settlements, therefore, the majority of these children have no possibility to go to school. Those who have formal education e.g. primary, secondary school or tertiary are either villagers or those having relatives in the towns or being in boarding school. Somalia's nomadic people do not possess basic literacy skills. Their children do not have access to basic education. Somalia's nomads, therefore, arguably need a better understanding of their socio-cultural predicament, which many consider as less developed.

According to [27], it is estimated that there are between 25 million and 40 million children of school age living in nomadic or pastoralist households of whom only between $10 \%$ and $50 \%$ attend school. Between 15 million and 25 million of the estimated 100 million of outof-school children are probably nomads and pastoralists. While rates of participation and completion of basic education for pastoralist boys are very low, the rates for girls are far lower.

[37] noted that since the colonial era the education system was never conducive to Somalia's pastoral communities as it has been generally characterized by low enrolment, male-biased and urban (or settlement) orientation features. They added that $5-10 \%$ of all school children were enrolled, of which girls constituted less that $20 \%$ of the total enrolment.

According to [28], there is little evidence, however, that pastoralist education has been addressed through major national initiatives in any country, with the exceptions of Uganda and Mongolia, since the World Education Forum in 1990.

Women's lack of education and resulting high rates of illiteracy were revealed in this survey. The possible explanation is that girls in pastoralist households have little chance to get education opportunity due to, early marriage, 
housework or cultural barriers. The main reason for early marriage is to get wealth return called "Yarad" in Somali from the bridegroom; mainly camel or cattle, since they are the most important wealth among the pastoralists. Besides the economic and the early marriage factors, most of the pastoral communities have strong cultural belief and they are afraid that girls would behave immorally if sent to school.

Results of the present study are consistent with the findings of previous Participatory Rural Appraisal studies carried out by the Alternative Basic Education for Karamoja programme working with pastoralist groups in Uganda [29]. Their findings show that early marriages have denied many girls the chance to realise their potential, and men dominate decision making at household and community levels.

Similar research carried out in among pastoralist communities in north-eastern Mali and western Niger, Oxfam GB indicate that, attendance and participation by pastoralist girls in formal schooling is hindered by a range of issues, including early marriage, their excessive workloads, popular beliefs that women are inferior to men and less intellectually able, and widespread poverty (ibid).

Education plays an indispensable role in addressing critical challenges of development. A sound and effective system of higher education provides solutions to a whole range of challenges plaguing society, globalization, poverty alleviation and democracy.

\subsubsection{Main Source of Household Income}

Occupations and associated total annual household income level of respondents varied greatly between different categories in the study areas. Result indicates that pastoralism was the main source of household income in the study areas, as over $70 \%$ of the population are nomadic pastoralist. In spite of fragile ecosystems of the area, results revealed that woody plants and woodlands constitute other important sources of household income including essential goods and services, income, employment and capital. Although the communities continued to rely on livestock production, it was realized that communities lacked diversity in utilization patterns, and technologies for promoting multi-production systems.

Informal employment (e.g. petty trading) was also noted as a major means of household income. A possible explanation is that the study areas are close to the borders of Somalia and Ogaden (eastern Ethiopia), therefore, there are potential markets and people are trading between the borders.

Fuelwood supports lucrative local trade. Trade in charcoal is a major source of income for many households. Other important source of household income as indicated by the respondents is remittance. Since the Somali civil war began in 1988, there have been large movements of people from Somalia to neighbouring countries, and unprecedented levels of migration to Europe and North America. Remittances have assumed great importance in this context [3]. At the household level, recent studies show that remittances constitute $40 \%$ of the income of urban households [31].

\subsubsection{Sources of Water}

Water scarcity is the major problem in the area. Since the area is dry by nature; low precipitation and high evapo-transpiration with no perennial rivers, the people in the study area primarily depend on man-made water sources like boreholes and rainwater harvesting namely constructed ground reservoirs which is expensive for the average households and earthen dams occasionally. However, these sources do not provide water throughout the year; the reservoirs dry up during the dry season due to decrease in precipitation or prolonged droughts. Other methods of rainwater harvesting like the use of earth dams is not efficient and not applicable in most parts of the area, particularly in Addado and Galkaayo, due to a high proportion of sand in the soil. Sandy soils are characterized by low water holding capacity. Recent studies by [7] show that soil with a high proportion of sand is unsuitable for dam construction. A sandy soil may be used in the downstream shoulder but should not be used elsewhere unless there is no alternative. In case a sandy soil is used in the rest of the dam, careful attention must be paid to compaction, the best soil reserved for the core, and some consideration given to obtaining embankment water tightness by other means. Sands play important role in larger dams as a filter material [7].

\subsubsection{Sources of Energy and Alternative Energy Preferences}

As common in the vast majority of the rural communities in sub-Saharan Africa, wood is the main sources of energy in the study area. The study area residents use firewood or charcoal as main sources of energy for cooking (Fig. 9). Results of the present study are consistent with the findings of [18] and [43] who found that approximately $90 \%$ of the population in sub-Sahara Africa relies on fuelwood and charcoal as sources of energy. Fuelwood and charcoal do not provide only energy but also employment and income generation in the Horn of Africa e.g. one-third of the wood-based energy consumption of Addis Ababa come from fuelwood $[18 ; 11]$. Similar researches conducted in Zambia by [18] and [12] also indicate that charcoal production provides 41,000 jobs in Zambia. The same authors reported that Zambian forest resources contribute nearly three-quarters of the total poor households income and one-third of the richer households' income.

Firewood problem, formerly of women has become a common issue in the study area affecting every member of the family. Women spend an average of one to two hours per day collecting firewood. In order to solve the problem of wood based energy, in terms of quality and availability, the group proposed to plant high energy efficient local species for firewood in community forest to overcome wood scarcity.

Majority of the study area residents indicated solar cooking as their most preferred alternative energy for 
cooking. They found it the most affordable alternative energy as compared to other alternatives.

\subsubsection{Land Tenure}

In the study area, four different types of land tenure systems were discovered, namely; communal land, freehold, state land and rented land. Communal land ownership and freehold land right were the two most common land tenure systems in the area. Some earlier studies confirm that customary systems are the de facto systems of land tenure in operation in many dryland zones, rather than statutory laws. In Africa, for example, most people hold their land under indigenous customary systems irrespective of formal legal position [34]. By clearing a piece of land or fencing, gives an individual the right to own that land under freehold. However, the study areas residents confessed that the land tenure systems were sometimes complicated and necessitated mutual understanding and relationship between pastoralists in the area and neighbouring pastoral communities.

\subsubsection{Major Causes of Environmental Changes}

The natural resource base in the study areas continue to be seriously threatened, disappearing or degrading at alarming rate due to deforestation, long spells of droughts, expansion of reservoir constructions and over-grazing. Facts distilled from the analysis undertaken at the household level revealed the following:

\subsubsection{Drought}

Information obtained from study areas residents revealed that droughts endangered and exacerbated poverty in the area; where an average household was said to lose $40 \%$ of its livestock in each drought event. The effects of the drought are not only limited to the loss of livestock, but comprise also food deficiencies, food quality, high rate of land degradation, loss of life and a drastic reduction of the water resources particularly of pastoral communities. By their very nature, agriculture in the drylands is exposed to the vicissitudes of an irregular rainfall pattern or frequent drought. Uncertainty in production due to fluctuations in total rainfall and changes in its distribution, decrease in relative productivity in rainfed lands etc. affect the livelihoods of many poor and marginalised pastoralists in the area. [31], studied the causes of desertification in the Horn of Africa and found that, recurring droughts leading to desertification in the Horn of Africa have created grave ecological catastrophes prompting massive food shortages.

\subsubsection{Deforestation Caused by Charcoal Burning}

Deforestation occurs in two forms: land conversion for other uses, mainly crop production/building up (urbanization), and cutting of woody plants in search of extra incomes or household consumption, i.e. for energy, construction, fences etc. In the area charcoal burning is graded as the second main cause of deforestation and desertification. For the last fifteen years charcoal trading was among the most important export commodity in the country, generating millions of dollars per year. Forests and woodlands cover approximately $23 \%$ of the country and are dominated by Acacia species. There has been significant, but localized, deforestation for agriculture, firewood and charcoal. Trees are the most important terrestrial resource because of the goods they provide, particularly in dry times [41].

As a result of prolonged civil war and frequent droughts many pastoralists and agro-pastoralist ended up as IDPs. Therefore, due to lack of other opportunities, many poor men (IDPs) found charcoal burning as an option of income generating (tragedy of the commons). The price of the charcoal depend o the quality of the charcoal; the best quality is the one with high energy efficiency and of course every tree cannot produce good quality charcoal, thereby the charcoal burners target specific tree species. Among the most extensively logged trees for charcoal production are the centenarian trees of Acacia tortilis and Acacia busei. These trees are locally important multi-purpose trees with high socio-economic and ecological benefits. Thereby, such exploitation activities of the aforementioned species caused numerous social and environmental problems. Hence, the civil societies, scholars and international NGOs were writing about the charcoal issue for the last ten years or so. In response, the local administrations in these areas issued a law banning cutting of Acacia tortilis and Acacia busei species. However, due to lack of capacity for law enforcements the problem still continues. On the other hand, the law permits utilization of dead tree (s) of these species for charcoal production; therefore, the charcoal burners developed new techniques. They started contaminating the tree's root system in order to kill the tree (s) by putting salt and used engine lubricants in the root level of the trees and eventually the trees die and they use it for charcoal production. Fortunately the issue of charcoal industry in Somalia is now highly politicized in the international level. Earlier this year the United Nations Security Council passed a resolution banning Somali exports of charcoal [42].

\subsubsection{Expansion of Reservoir Construction}

As means of coping strategies the local people adapted rainwater harvesting through constructed underground reservoirs as a source of water. However, during the field assessment it was observed that reservoirs cause tremendous environmental impact. Problems around these areas consist of overstocking, large-scale vegetation depletion and changes, especially around water points, and accelerated soil erosion by wind, sheet and gully. Bare soil areas are conspicuous around water points in Addado, Buhodle and Northern Galkaayo of Central and Northern Somalia as a result of heavy grazing. Similar studies conducted in other parts of the Horn of Africa revealed that water points are starting points of desertification. Soil and vegetation degradation around watering points has been observed in many drylands around the world. It can be recognized in space-borne imagery as radial brightness belts fading as a function of distance from the water wells [20]. 
It is known that reservoir expansion in the area is the third major problem causing environmental degradation for the following reasons;

1) Since the land is communally owned, there is big resources competition among the people in the area, each one trying to get the most appropriate place to construct his/her reservoir; therefore, the reservoirs are neither collectively owned nor concentrated in one place, but individually owned and scatted in the grazing land. That means there are tens or even hundreds of water points in each project area.

2) Every reservoir owner fences approximately one hectare of land around the reservoir as watershed area using dead fencing which causes huge deforestation.

3) Branches, shrubs and Andropogen kelleri locally known as (duur), are used to cover reservoir to avoid water loss through evaporation. These cause fodder shortage and soil exposure to wind and water erosion, resulting in desertification.

\subsubsection{Overgrazing}

Table 4. List of over exploited species as indicated by the respondents

\begin{tabular}{lllll}
\hline Species (Scientific Name) & Somali Name & Species Type & Specific Area & Reason (S) of Exploitation \\
\hline Andropogen kelleri & Duur & $\mathrm{G}$ & $\mathrm{B}$ & Thatching and covering reservoirs \\
Chrysopogon plumulosus & Dareemo & $\mathrm{G}$ & $\mathrm{A}, \mathrm{B}, \mathrm{GK}$ & Overgrazing, drought and thatching \\
Sporobolus marginatus & Dixi & $\mathrm{G}$ & $\mathrm{B}$ & Overgrazing, making mats and drought \\
Ziziphus mauritaniana & Gob & $\mathrm{T}$ & $\mathrm{A}, \mathrm{B}, \mathrm{GK}$ & Construction, fencing, drought \\
Riurosoefigyy dkikdjtiujAca cia tortilis & Qudhac/Qurac & $\mathrm{T}$ & $\mathrm{A}, \mathrm{GK}$ & Charcoal production \\
Acacia busei & Galool & $\mathrm{T}$ & $\mathrm{A}, \mathrm{GK}$ & Charcoal production \\
Commiphora myrrha & Dhidin/geed malmal & $\mathrm{T} / \mathrm{Sh}$ & $\mathrm{A}, \mathrm{GK}$ & Fencing, drought, tapping \\
Commiphora stellatoubescens & Xoday & $\mathrm{T} / \mathrm{Sh}$ & $\mathrm{A}, \mathrm{GK}$ & Carving, drought, fencing \\
Cordia sinesis & Madheedh/Mareer & $\mathrm{Sh}$ & $\mathrm{A}, \mathrm{GK}$ & Construction, overgrazing, drought \\
Dobera glabra & Garas & $\mathrm{T}$ & $\mathrm{A}, \mathrm{B}, \mathrm{GK}$ & Poles, carvings and seed over harvesting \\
Balanites aegyptiaca & Quud/Iriiri & $\mathrm{T}$ & $\mathrm{A}, \mathrm{GK}$ & Charcoal production, construction poles \\
Grewia villosa & Gomoshaa & $\mathrm{Sh}$ & $\mathrm{A}, \mathrm{B}, \mathrm{GK}$ & Overgrazing, fruit overharvesting, drought \\
Grewia tenax & Dhafaruur & $\mathrm{Sh}$ & $\mathrm{A}, \mathrm{B}, \mathrm{GK}$ & Fruit overharvesting, drought, overgrazing \\
Grewia bencilities & Hohob & $\mathrm{Sh}$ & $\mathrm{A}, \mathrm{B}, \mathrm{GK}$ & Fruit overharvesting, drought, overgrazing \\
Acacia milifera & Bilcil & $\mathrm{T} / \mathrm{Sh}$ & $\mathrm{A}, \mathrm{GK}$ & Fencing \\
Terminalia spinosa & Lebi & $\mathrm{T}$ & Curving and low germination \\
\hline
\end{tabular}

Note: $\mathrm{A}=$ Addado, $\mathrm{B}=$ Buhodle, $\mathrm{GK}=$ Galkaayo, $\mathrm{G}=$ Grass, $\mathrm{Sh}=$ Shrub and $\mathrm{T}=$ Tree

Overgrazing is another important factor causing desertification. The possible explanations of overgrazing is that both livestock from the area and from the neighbouring communities make excessive use of the limited fodder resources, in the silvopastoral areas, which is a communal resource, freely available for everyone. Livestock and other wildlife are mostly browsers; damage the barks of woody perennials leading to outbreak. Land tenure arrangements was a disincentive to conservation i.e. fencing off some areas was not acceptable at the individual level.

Pastoralism in the three study areas were rapidly worsening at an alarming rate due to frequent droughts, charcoal production, reservoir construction and overgrazing which continued to adversely affect the quality of the pastures in the area. The situation was also aggravated by influx of livestock from neighboring districts as well as from neighboring country of Ethiopia. This influx continued to exert increased pressure on an already fragile eco-system. It is estimated that over $60 \%$ of pastoral communities within the study areas live below the poverty line. Poverty in the study areas may be attributed to declined soil fertility, soil erosion, shortage of fodder for livestock, shortage of fuel-wood and other wood products, limited income and unsuccessful land use practices. The forests in Somalia are suffering heavy exploitation and degradation reflected in negative effects on species composition and ecosystem services [2]. The following species are most exploited species as indicated by study area residents respondents (Table 4).
There are also many disappeared edible plant species which were locally important sources of nutrition. These species naturally which grow in association with grasses like Andropogen kelleri and Chrysopogon plumulosus, but as a result of habitat destruction these species disappeared. Such important vegetables including several of Cucumis species among them is Cucumis metuliferus syn. Horned cucumber and other herbs with edible roots.

\subsubsection{Willingness to Participate in NTR and Planting \\ Trees for Agroforestry Purpose}

Generally, a considerable number of local people already had considerable amount of experiences of benefits acquired from trees and other vegetation resources, and expressed their willingness to adopt agro-silvo-pastoral system. The most important result found on this issue was the willingness among the majority of the local people, especially women, to participate in tree planting. The emphasis was stronger among women as compared to men. Clearly, over $90 \%$ of women wanted to have more trees, for income generation and satisfaction of their basic needs from the sale of products.

Majority of men also found tree planting acceptable; although some had different perceptions about its practicality and how it could be managed. Likewise, responses received from a cross-section of respondents showed that the most important restraint were livestock grazing and unclear ownership. Results also indicate that men who showed interest in planting trees, found integration of trees with their 
own farmlands acceptable. One reason is that the Somali community respects ownership. Similar studies by [8] in the Sudan showed that land tenure and land security are crucial issues for the success of any tree planting projects. However, the result of the current study shows that, land availability was not the limiting factor; because over sixty percent of the land was considered as communal, where every member of the community had right to plant trees.

\section{Conclusion}

The present study examined the state of the environment as well as the socio-economic and ecological impacts of environmental degradation in Addado, Buhodle and Galkaayo in central and northern Somalia. The mounting pressure on the area's natural resources due to increasing drought events, deforestation, expansion of reservoirs and overgrazing has resulted in a high level of resource exploitation and environmental degradation which adversely affect the livelihood of the people in the areas.

Against this backdrop, there is an immediate need of action for seeking newer approaches in the farming systems to meet the basic needs of the local people. Adoption of tree planting/agroforestry on a wide range of land in the area and incorporation of multipurpose trees in the existing farming systems seem to be an apt option for reducing the pressure on the natural vegetation and for promoting self-sustaining. Agroforestry is the most preferred resource management system, because it has the potential to stabilize the production of food, forage, firewood and timber and protecting the environment. In agroforestry, crop productivity is enhanced under tree canopy due to improved soil fertility and the ameliorative influence of shade in a hot dry environment by reducing the understory temperature and mitigating evapo-transpiration. However, this requires development of appropriate skills, implementation capacity and the presence of institutions at the local, regional and national levels so as to ensure the effective use of existing resources and to foster the mobilization of additional financial and human resources for continued development of the subsistence sector.

\section{References}

[1] Benton, H. H. 1973-1974. Encyclopaedia Britannica, Inc. Ready Reference and Index volume VII, Publisher University of Chicago.

[2] Bongers F. and Tennigkeit T. (eds), 2010. Degraded Forests in Eastern Africa: Management and Restoration. Earthscan, UK.

[3] DFID, 2005. Somalia Country Study. European Community's Poverty Reduction Effectiveness Programme (EC-PREP). University of Oxford, Oxford, UK.

[4] Dixon, R.K., Winjum, J.K., Andrasko, K.J., Lee, J.J. and Schroeder, P.E., 1994. Integrated land-use systems: assessment of promising Agroforestry and alternative land-use practices to enhance carbon conservation and sequestration. Climate Change 27:71-92.

[5] Faillace, C. And Faillace, E. R. 1987. Water quality data book of Somalia. General report. Deutsche Gesellschaft für Technische Zuzammenarbeit (GTZ) GMBH. Project No. 80.2193.3-09.112.

[6] FAO, 1993. Key aspects of strategies for the sustainable development of Drylands. Rome.

[7] FAO, 2010. Manual on Small Earth Dams: A Guide to Siting, Design and Construction. FAO, Rome. Irrigation and Drainage Paper 64.

[8] Glover, E. K. 2005. Tropical dryland rehabilitation: Case study on participatory forest management in Gedaref, Sudan. Doctoral Dissertation, University of Helsinki Tropical Forestry Report No. 27. 183 p.

[9] Glover, E.K. 2010. Approaches to Halt and Reverse Land Degradation in Kenya: Agroforestry Development and Environmental Sustainability. , 2010 VDM Verlag, Germany

[10] Grainger, A. 1990. The threatening desert: Controlling desertification. Earthscan Publications Ltd., London. 359 p.

[11] Haile, F. 1991. Women Fuelwood Carriers in Addis Ababa and the Peri-Urban Forest. Report to the Government of Norway, the International Development Research Centre and the National Urban Planning Institute, Geneva, International Labour Office.

[12] Hibajene, S. J. and A. Ellegard. 1994. Charcoal Transportation and Distribution: A Study of the Lusaka Market. Energy, Environment and Development Series 33, Stockholm Environment Institute, Stockholm.

[13] Hoffman, M. T. \& Todd, S. W. 2000. A national review of land degradation in South Africa: The influence of biophysical and socio-economic factors. Journal of Southern African Studies. 26 (4): 743-758.

[14] Huschke, R.E. (ed.) 1959. Glossary of meteorology: Boston, American Meteorological Society, $638 \mathrm{p}$.

[15] Iiyama, M., Kristjanson, P., Ogutu, J., Maitina, J., Kariuki, P., Morimoto, Y. And Baur, H., 2008. Conservation, natural resource management and development challenges in rural Africa: Evidence from east Africa. In: Natural Resources. Nover Science Publisher, Inc.

[16] IUCN 2001. Regional workshop on community involvement in forest management in Eastern and Southern Africa. IUCN Eastern Africa Programme, Kampala, Uganda. Forest and Social Perspectives in Conservation No. 6. 25 p.

[17] Kadomura, H. (ed.) 1997. Data book of desertification/land degradation. Centre for Global Research, National Institute for Environmental Studies (NIES), Japan. 68 p.

[18] Kaimowitz, D., 2002. Forests and Rural Livelihoods in Sub-Sahara Africa. Forests in Poverty Reduction Strategies: Capturing the potential. Tuusula, Finland EFI Proceedings 47 (2003),

[19] Karnieli A., U. Gilad, M. Ponzet, T. Svoray, R. irzadinov, O. Fedorina, 2008. Assessing land-cover change and degradation in the Central Asian deserts using satellite image processing and geostatistical methods. Journal of Arid Environments, 72: 2093-2105. 
[20] Kindt, R., van Breugel, P., Lillesø, J.-P.B., Bingham, M., Sebsebe Demissew, Dudley, C., Friis, I., Gachathi, F., Kalema, J., Mbago, F., Minani, V., Moshi, H.N., Mulumba, J., Namaganda, M., Ndangalasi, H.J., Ruffo, C.K., Jamnadass, R. and Graudal, L., 2011. Potential natural vegetation of Eastern Africa. Volume 3: Description and tree species composition for woodland and wooded grassland types. Forest \& Landscape Working Paper 63-2011

[21] Kürsten, E., 1999. Fuelwood production in Agroforestry systems for sustainable land use and $\mathrm{CO}_{2}$ mitigation. Ecological Engineering 6: 69-72.

[22] Mahony, D., 1990. Trees of Somalia. Field guide for development workers. Oxfam.

[23] Millennium Ecosystem Assessment, 2005. Ecosystems and Human Well-being. Dryland Systems. World Resources Institute, Washington, DC

[24] Mogaka, H., Gacheke, S., Turpie, J., Emerton, L. and Karanja, F., 2001. Economic Aspects of Community Involvement in Sustainable Forest Management in Eastern and Southern Africa.

[25] IUCN, 2001. Eastern Africa Regional Office Forest and Social Perspectives in Conservation, No. 8, Nairobi.

[26] Olsson, K. 1985. Desertification and land degradation on perspective. In: Poulsen, E. and Lawesson, J. (eds.). Dryland degradation: causes and consequences. Aarhus University Press. pp. 5-13.

[27] Oxfam GB, 2003. Achieving EFA through Responsive Education Policy and Practice for Nomadic and Pastoralist Children: What can Agencies do? Unpublished paper, Oxford: Oxfam GB

[28] Oxfam GB 2005a. Pastoralist Education Learning Resource: A compilation of information on pastoralist education programmes in Horn and East Africa', Nairobi.

[29] Oxfam GB, 2005b. Beyond the Mainstream, Education and Gender Equality Series, Programme Insights. Oxford: Oxfam GB.

[30] Pantuliano S. and Pavanello S. 2009. Taking drought into account: Addressing chronic vulnerability among pastoralists in the Horn of Africa, Overseas Development Institute, UK .
[31] Social Development Papers (SDP)，2006. Remittances and Economic Development in Somalia: An Overview. Conflict Prevention and Reconstruction, Paper No. 38/ November.

[32] Tyson, W., 1995. Ecosystem restoration: theory, practice, and evidence. In: Roundy, B.A., McArthur, E.D., Haley, J.S., Mann, D.K. (Compilers), Proceedings of the Wildland Shrub and Arid Land Restoration Symposium, Las Vegas, NV, October 19-21, 1993. General Technical Report INT-GTR-315. US Department of Agriculture, Forest Service, Intermountain Research Station, Ogden, UT, pp. 116-118.

[33] UNCED 1992. Report of the United Nations Conference on Environment and Development; Earth Summit Agenda 21. Rio de Janeiro, 3-14 June 1992. New York: United Nations. 300 p.

[34] UNDP, 2003. The Global Drylands Imperative: Land tenure reform and the Drylands. Drylands Development Centre. Nairobi, Kenya.

[35] United Nations Development Programme (UNDP) 2010. Assessment of Development Results: Evaluation of UNDP Contribution. Somalia Evaluation Office.

[36] UNEP, 1997. World atlas of desertification. Edward Arnold, London, UK.

[37] UNICEF-Somalia 1993. Strategies on Nomadic Education Delivery. Education Unit, United Nations Children's Fund (UNICEF) Somalia, UNICEF Somalia, Document 1103.

[38] World Bank, 2007. World Development Report 2008: Agriculture for Development. Washington DC: The World Bank.

[39] World Conservation Union (IUCN), 2006. Country Environmental Profile for Somalia. The European Commission Somalia Operations Office, Nairobi, Kenya.

[40] The National 2012. Charcoal exports from Somalia banned. Available at: http://www.thenational.ae/news/uae-news/charcoal-exportsfrom-somalia-banned Accessed on 30.3.2013 